\title{
SOCIAL CAPITAL DEVELOPMENT OF RURAL COMMUNITY BASED ON SOCIAL NETWORKING ACTIVITIES IN LITHUANIA
}

Judita KASPERIŪNIENÉ, Centre of Study Quality and Inovations, Department of Philosophy, Psychology and Vocational Education, Aleksandras Stulginskis University, Studentų g. 11, Akademija LT-53361, Kauno raj., Lithuania, judita.kasperiuniene@asu.lt (corresponding author)

Ilze IVANOVA, Department of Education sciences, Faculty of Education, Psychology and Art, University of Latvia, Jūrmalas avenue 76, Rīga, LV-1083, Latvia, ilze.ivanova@lu.lv

\begin{abstract}
The scholar literature on simultaneous using of social capital explore knowledge and identity resources as well as actions and interactions benefiting the community through personal bonds of individuals; issues of common trust; and adapting the current understanding in new situations. In this article, we instead examine rural community influence on social capital building of adult person in a virtual community. A quantitative survey was done in 246 local rural communities in Lithuania which reflected their community activities on a virtual basis. From the data of 500 informants we found that rural community (human social network) members were also active in the virtual communities. Research participants from rural communities expressed their will to be the part of a virtual community and virtually solve various local community issues. Active members of virtual communities actively participated in live community activities. Local community members peer-learned while sharing knowledge and experience in virtual communities. We argue that belonging to a virtual community inspire rural community members to train their virtual and live communication skills and peer-learn. Virtual community could contribute to self-regulated learning by stimulating sense of sociality and identity of rural community members. Virtual community could operate as self-regulated learning space for rural community members. Social capital development would be more intensive when the members of rural community actively engage in social communication, cooperation and exchange of information, and mentor each other. This survey highlights the virtual community influence the social capital building of rural community members in Lithuanian context.
\end{abstract}

Keywords: adult person, belonging, rural community, social capital development, virtual community

\section{INTRODUCTION}

Social capital (SC) in its different forms and contexts is researched for many years (Helliwell and Putnam, 2007; Lin, 1999; Portes, 1998). Despite that, SC development in urban and rural areas and communities remains an object for discussions and scholar investigation (Ellison et al., 2014). Granovetter (1992) researched and after twenty years Kwon et al. (2013) confirmed that i) individuals are influenced by other community members and social environments; ii) social capital functions as public good and creates public value.

In this study we followed Hunter (2002), defining a virtual community as "a group of adult persons who communicate, learn from each other's work, and provide knowledge and information resources to a group related to certain agreed-upon topics of shared interests". In contemporary virtual communities' people not only share interests, but communicate and find common social characteristics. Virtual communities are studied as groups of common interests (Issa and Kommers, 2013), professional connections (Connelly et al., 2015), or entertainment networks (Chang and Stamps, 2017). While studying different aspects of virtual communities, scholars agreed that surrounding physical and virtual context of adult persons directly influence the community and vice versa. In their research of internet effects on social capital, Wellman et al. (2001) argued, does the internet increase, decrease, or supplement interpersonal contacts, participation, and community commitments? From the data of more than 39,000 informants, Wellman et al. (2001) researched that i) online interaction supplemented physical communication without increasing or decreasing it; ii) persons who were extensive internet users were more involved in physical community issues such as volunteering or local politics; iii) virtually connected people felt that they belong to the physical community.

It is theoretically and empirically researched that a sense of belonging predicts the meaningfulness of life (Lambert et al., 2013). In his study of self-presentation and belonging on Facebook, Seidman (2013) confirmed Lambert et al. (2013) findings and examined links in personality and motivation to participate in virtual communities. Following these authors, we examined two aspects of belonging: i) feeling like a member of a group or community (virtually or physically); ii) attaching to individual or community because of similar values, believes or common activities. Additionally, we Copyright (C) 2017 The Authors. Published by Aleksandras Stulginskis University. This is an open-access article distributed under the terms of the Creative Commons Attribution License (CC-BY 4.0), which permits unrestricted use, distribution, and reproduction in any medium, provided the original author and source are credited. 
supported and extended Falk and Kilpatrick (2000) definition of social capital in a rural community stating that interactive processes are crucial in building community social capital and rely on persons knowledge and identity resources with new component - social networking resources. Two research questions were raised: i) How the social capital is developed in a contemporary rural community? ii) How social networking activities and participation in virtual community influence self-regulated learning of local community members?

\section{METHODOLOGY}

Analytical framework. We supplemented Falk and Kilpatrick (2000) conceptual, theoretical and analytical approach of simultaneous building and using social capital in a rural community with new component - social networking resources, virtually created by local community members for local community needs. The flow of interaction is shown by arrows. Interaction means physical or virtual communication, sharing and learning of rural community members inside and outside the community. Additionally, we added belonging component to our analytical framework. Belonging in a rural community context is understood as relationship with its forming elements: individual and physical community values, attitudes and believes; liabilities and commitments to physical and virtual community; communion with virtual group and friends. Virtual and physical belonging is similar (Fig. 1).

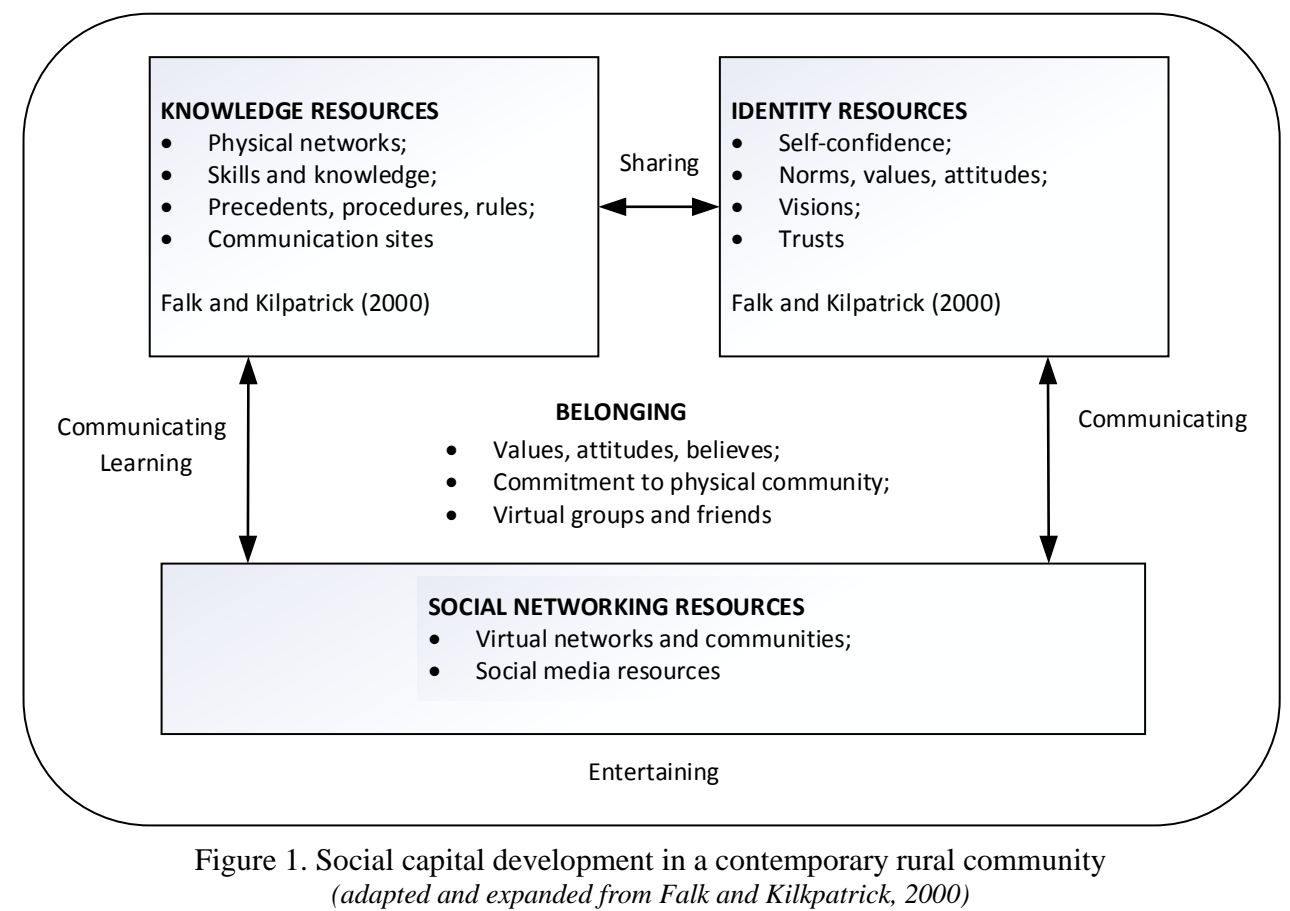

Methods. Quantitative strategy was chosen for the empirical research. The research instrument consisted of three scales: i) social capital with focus on general rural community issues; ii) virtual activities and level of social networking; iii) individual needs and learning possibilities. The rural inhabitant social capital with focus on general rural community issues was measured using adapted Williams (2006) social capital (7 statements) and adapted Bollen and Hoyle (1990) perceived cohesion ( 5 statements) measurements. This first scale (Cronbach's $\alpha=0.902 ; M=3.33, S D=0.77$ ) aimed at measuring the strength of the relationships between rural communities that are involved in the activities of the social network. Virtual activities and level of social networking was measured using 12 statements original scale and 12 statements adapted Bishop et al. (1997) perceived sense of community scale (Cronbach's $\alpha=0.812 ; M=3.77, S D=0.56$ ). Individual needs and learning possibilities were measured using original scale (5 statements), Brookhart et al. (2006) adapted questionnaire (6 statements) and Brown et al. (1999) adapted self-regulation questionnaire (Cronbach's $\alpha=0.910 ; M=3.47, S D=0.73$ ). All the constructed scales used Likert-type response items (Allen and Seaman, 2007). Informants had the possibility to specify their level of agreement or disagreement in five-point system.

Informants. Based on a community list from bendruomenes.lt portal, the local communities having social networking groups were selected. From this list, 156 local communities with the mirroring virtual community profiles participated in the research. Additionally, 88 communities were found using electronic search engines and keywords "community", "community center", "community house" and "community friends". All the 246 virtual communities united 54757 community members. The largest virtual community consisted of 3216 members (Rokiskis community) and smallest -4 members (Birbinciai community). Online questionnaire was virtually provided to all the communities. If the local community had closed virtual community group, informants were contacted personally or through virtual community group administrators. The questionnaire was answered by 500 local community members. The survey was conducted twice: in first months of 2015 and in the middle of 2016. 


\section{RESULTS}

Demographic data analysis. 500 adult local community members participated in research. The $80.0 \%$ of the informants were female. The data stating that $58.0 \%$ of informants were 30 to 49 years old indicated that middle-aged persons from rural areas were more engaged in the virtual community activities. $77.0 \%$ of informants indicated having higher education. This indicator informed that community activities are mostly carried out by people with higher education. $61.0 \%$ of informants were full-time employees in public or private sector enterprises. 54.4\% of informants explained that they read the virtual community posts several times per day, while $21.0 \%$ of them were all the time online checking community news. These indicators stressed that community-based activities were an important concern. Research participants virtually observed physical community events, followed the community news and other related information, and participated in discussions.

Empirical analysis on social capital and rural community development. Informants activity was clustered into two intensity groups: i) active networking and ii) passive networking. Data showed that research participants were more active than passive in virtual settings. Active and passive networking activities were treated as social networking resources helping to develop the social capital (Fig. 1).

Only $2.0 \%$ of informants indicated that they used their virtual accounts less than 3 times a week. 54.0\% of participants logged in to their Facebook account (virtual community group) several times a day. $21.0 \%$ were constantly online from their devices. It could be concluded that most informants were active social network members.

Five virtual community activity groups were distinguished: active sharing; active communicating; passive and active belonging; active and passive learning and active entertaining. Passive activities covered sometimes following groups, persons and institutions (34.0\% of informants) and very often learning from practical examples (31.0\%). Besides that, some informants actively peer-learned. The most popular active virtual activity was always advertising personal or community activities (26.0\%) and sharing texts (38.0\% sometimes and 38.0\% very often were involved into the activity). Belonging to a virtual group was expressed more passively (34.0\% sometimes followed groups, people and institutions) than actively (16.0\% always administered virtual communities). Playing online games (1.0\% always played) remained the less popular activity (Table 1).

Table 1. Informants networked activity frequency in a virtual community

\begin{tabular}{|c|c|c|c|c|c|c|c|c|}
\hline \multirow[b]{2}{*}{ No } & \multirow{2}{*}{\begin{tabular}{c|} 
Virtual \\
community \\
activity \\
\end{tabular}} & \multirow[b]{2}{*}{ Explanation } & \multirow[b]{2}{*}{ Intensity } & \multicolumn{5}{|c|}{ Frequency (in percentage), $\mathrm{n}=500$} \\
\hline & & & & $\begin{array}{c}\text { Neve } \\
\mathbf{r}\end{array}$ & $\begin{array}{c}\text { Seldo } \\
\mathbf{m}\end{array}$ & $\begin{array}{c}\text { Sometime } \\
\mathbf{s}\end{array}$ & $\begin{array}{l}\text { Very } \\
\text { often }\end{array}$ & \begin{tabular}{|c|} 
Alway \\
s
\end{tabular} \\
\hline & Sharing & $\begin{array}{l}\text { Posting pictures, photos, videos to virtual community } \\
\text { wall }\end{array}$ & \multirow[t]{5}{*}{ Active } & 6 & 34 & 32 & 22 & 6 \\
\hline & & Sharing texts & & 5 & 11 & 38 & 38 & 8 \\
\hline & & Liking other people posts & & 6 & 20 & 41 & 25 & 9 \\
\hline & & Advertising community activities & & 24 & 11 & 17 & 22 & 26 \\
\hline & & Creating new events & & 23 & 30 & 31 & 14 & 2 \\
\hline \multirow{2}{*}{\multicolumn{2}{|c|}{\begin{tabular}{|l|l|}
2 & Communicatin \\
$\mathrm{g}$
\end{tabular}}} & Commenting openly other people posts and pictures & \multirow[t]{2}{*}{ Active } & 2 & 23 & 34 & 35 & 6 \\
\hline & & Messaging privately & & 10 & 22 & 42 & 18 & 8 \\
\hline \multirow{2}{*}{\multicolumn{2}{|c|}{3 Belonging }} & Following groups, people, institutions & Passive & 8 & 28 & 34 & 25 & 5 \\
\hline & & Administering and moderating groups & Active & 45 & 6 & 19 & 14 & 16 \\
\hline & Learning & Learning from practical examples & $\begin{array}{l}\text { Active, } \\
\text { passive }\end{array}$ & 10 & 24 & 28 & 31 & 7 \\
\hline & Entertaining & Playing games & Active & 75 & 12 & 6 & 6 & 1 \\
\hline
\end{tabular}

(social networking resources)

Rural community activities were reflected in virtual communities as community knowledge and identity resources (Fig. 1). Data from sharing, communicating and learning showed how community knowledge resources were virtually created. $51.0 \%$ of active rural community members shared the information about the village events and physical community activities in a virtual community. Passive community members (46.0\%) disagreed with this. This disagreement was influenced by rural community members preunderstandings and imaginations that were not proven. Both group members - active (73.0\%) and passive (46.0\%) - shared their personal life issues. Active virtual community members provided personal opinions (46.0\%). Passive community member answers distributed almost evenly: $31.0 \%$ agree, $38.0 \%$ disagree and $31.0 \%$ had no opinion. Both groups - active and passive - agree, that in a virtual community they could found peers and interlocutors and communicated with them. The opinions about learning in virtual community were different: active virtual community members applied for professional advice to other community members through social media $(60.0 \%)$ and passive virtual community members behave differently $(38.0 \%$ not applied for advices and $39.0 \%$ neither agree nor disagree on this). These data explained that physical networks could be expanded using social media tools. Various skills and knowledge could be developed in virtual communities.

Belonging showed how identity resources could be virtually created. Both informant groups felt communion with other members, felt belonging to a virtual community and happiness "being a member of the community". Besides that, only active virtual community members trusted their virtual peers (54.0\%). Passive members oppositely - did not trusted $(46.0 \%)$ or had no opinion $(39.0 \%)$. These controversial data explained the importance of becoming active member of a virtual community. Virtual activity could influence persons self-confidence, values, attitudes and visions. 
Table 2. Intensity of rural community activities mirroring in a virtual community

\begin{tabular}{|c|c|c|c|c|c|c|}
\hline \multirow{2}{*}{ No. } & \multirow{2}{*}{$\begin{array}{l}\text { Virtual } \\
\text { community } \\
\text { activity }\end{array}$} & \multirow{2}{*}{ Explanation } & \multirow{2}{*}{$\begin{array}{l}\text { Intensity } \\
\text { (A-active, } \\
\text { P-passive) }\end{array}$} & \multicolumn{3}{|c|}{ Frequency (in percentage), $n=500$} \\
\hline & & & & Agree & Disagree & $\begin{array}{l}\text { Neither agree } \\
\text { nor disagree }\end{array}$ \\
\hline \multirow[t]{6}{*}{1} & \multirow[t]{6}{*}{ Sharing } & \multirow{2}{*}{$\begin{array}{l}\text { Sharing information about village, } \\
\text { neighborhood or surrounding area } \\
\text { activities and events }\end{array}$} & A & 51 & 37 & 12 \\
\hline & & & $\mathrm{P}$ & 23 & 46 & 31 \\
\hline & & \multirow{2}{*}{ Sharing personal life issues } & $\mathrm{A}$ & 73 & 11 & 16 \\
\hline & & & $\mathrm{P}$ & 46 & 15 & 39 \\
\hline & & \multirow{2}{*}{ Providing personal opinions } & A & 46 & 29 & 25 \\
\hline & & & $\mathrm{P}$ & 31 & 38 & 31 \\
\hline \multirow[t]{2}{*}{2} & \multirow[t]{2}{*}{ Communicating } & \multirow{2}{*}{$\begin{array}{l}\text { Founding peers and interlocutors when } \\
\text { communicating }\end{array}$} & A & 80 & 8 & 12 \\
\hline & & & $\mathrm{P}$ & 62 & 8 & 30 \\
\hline \multirow[t]{8}{*}{3} & \multirow[t]{8}{*}{ Belonging } & \multirow{2}{*}{$\begin{array}{l}\text { Trusting the members of virtual } \\
\text { community }\end{array}$} & A & 54 & 35 & 11 \\
\hline & & & $\mathrm{P}$ & 15 & 46 & 39 \\
\hline & & \multirow{2}{*}{ Feeling communion with other members } & A & 76 & 5 & 19 \\
\hline & & & $\mathrm{P}$ & 69 & 8 & 23 \\
\hline & & \multirow{2}{*}{ Feeling belonging to a virtual community } & A & 79 & 8 & 13 \\
\hline & & & $\mathrm{P}$ & 62 & 0 & 38 \\
\hline & & \multirow{2}{*}{$\begin{array}{l}\text { Feeling the happiness being a member of } \\
\text { the community }\end{array}$} & A & 66 & 11 & 23 \\
\hline & & & $\mathrm{P}$ & 62 & 8 & 30 \\
\hline \multirow[t]{2}{*}{4} & \multirow[t]{2}{*}{ Learning } & \multirow{2}{*}{$\begin{array}{l}\text { Applying for professional advice to other } \\
\text { community members }\end{array}$} & A & 60 & 21 & 19 \\
\hline & & & $\mathrm{P}$ & 23 & 38 & 39 \\
\hline
\end{tabular}

(community knowledge and identity resources)

Answers indicated that the difference in community activity (sharing, communicating, belonging and learning) for active and passive virtual community members were small. Besides that, active rural community members did not express bigger willingness to belong to the virtual community than passive.

\section{CONCLUSIONS}

We found that social capital in a contemporary rural community is developed in two ways: i) physically contacting and connecting other rural community members and ii) virtually participating in a networked group or community which is formed to discuss the rural community issues. We adapted and expanded Falk and Kilkpatrick (2000) model of social capital development with the third component - social networking resources. Through qualitative research we empirically proved the role of social networking and virtual community to physical community.

We divided virtual community activities to sharing, communicating, belonging, learning, entertaining and examined the technologically active and passive community member's behavior in a virtual community. We found only small virtual activity differences in active and passive community members.

Self-regulated learning in a virtual community was developed mostly from other participants' stories and good practice examples. Active community members were also active in virtual communities. They constantly developed their communication skills and peer-learned.

\section{LIMITATIONS}

In a contemporary growing world virtual community develops together with new technical tools and social innovations. Rural communities also change. The rural community in Lithuania is aging, many people work in cities. Smart technologies allow persons to be connected all the time. Modern technical capabilities enable community members to constantly keep track of their community's life. In our research we didn't asked about the smart device usage, community aging and similar issues. How these modern technologies and modern life influence the social capital building and how the rural community members specifically behave in virtual communities need to be additionally researched in Lithuanian and neighboring country contexts.

\section{Acknowledgement}

Authors thank to Simona Balciuviene, formerly master student at Professional education study programme (Aleksandras Stulginskis University) for her contribution in finding the rural and virtual communities, constructing the online questionnaire version and collecting some very fruitful qualitative data.

\section{REFERENCES}

1. Allen, I.E., Seaman, C. A. 2007. Likert scales and data analyses. Quality progress, Vol. 40(7), pp. 64-65.

2. Bishop, P.D., Chertok, F., Jason, L.A. 1997. Measuring sense of community: Beyond local boundaries. The Journal of Primary Prevention, Vol. 18(2), pp. 193-212. https://doi.org/10.1023/A:1024690424655 
3. Bollen, K.A., Hoyle, R.H. 1990. Perceived cohesion: A conceptual and empirical examination. Social forces, Vol. 69(2), pp. 479-504. https://doi.org/10.1093/sf/69.2.479

4. Brookhart, S.M., Walsh, J.M., Zientarski, W.A. 2006. The dynamics of motivation and effort for classroom assessments in middle school science and social studies. Applied Measurement in Education, Vol. 19(2), pp. 151-184. https://doi.org/10.1207/s15324818ame1902_5

5. Brown, J.M., Miller, W.R., Lawendowski, L.A. 1999. The self-regulation questionnaire.

6. Carey, M.C., Meyer, H.K. 2016. The influences of participation and moderation on the development of a sense of virtual community. International Journal of Web Based Communities, Vol. 12(4), pp. 326-341. https://doi.org/10.1504/IJWBC.2016.10001834

7. Chang, E., Stamps, D. 2017. Characterization of teen SNS usage in entertainment media. In Consumer Electronics (ICCE), 2017 IEEE International Conference on (pp. 76-77). https://doi.org/10.1109/ICCE.2017.7889236

8. Connelly, M., Beals, A., VanDerlip, A., Singaraju, K., Weintraub, R. L. 2015. Professional virtual communities for health care implementers: impact of participation on practice. Iproceedings, Vol. 1(1). https://doi.org/10.2196/iproc.4695

9. Ellison, N. B., Vitak, J., Gray, R., \& Lampe, C. (2014). Cultivating social resources on social network sites: Facebook relationship maintenance behaviors and their role in social capital processes. Journal of Computer-Mediated Communication, Vol. 19(4), pp. 855-870. https://doi.org/10.1111/jcc4.12078

10. Falk, I., Kilpatrick, S. 2000. What is social capital? A study of interaction in a rural community. Sociologia ruralis, Vol. 40(1), pp. 87-110. https://doi.org/10.1111/1467-9523.00133

11. Granovetter, M. 1992. Economic institutions as social constructions: a framework for analysis. Acta sociologica, Vol. 35(1), 3-11. https://doi.org/10.1177/000169939203500101

12. Helliwell, J.F., Putnam, R.D. 2007. Education and social capital. Eastern Economic Journal, Vol. 33(1), pp. 1-19. https://doi.org/10.1057/eej.2007.1

13. Hunter, B. 2002. Learning in the virtual community depends upon changes in local communities. Building virtual communities: Learning and change in cyberspace, pp. 96-126. https://doi.org/10.1017/CBO9780511606373.009

14. Yang, S.J. 2006. Context aware ubiquitous learning environments for peer-to-peer collaborative learning. Educational Technology \& Society, Vol. 9(1), pp. 188-201.

15. Issa, T., Kommers, P. 2013. Social networking for web-based communities. International journal of web based communities, Vol. 9(1), pp. 5-24. https://doi.org/10.1504/IJWBC.2013.051292

16. Kwon, S.W., Heflin, C., Ruef, M. 2013. Community social capital and entrepreneurship. American Sociological Review, Vol. 78(6), pp. 980-1008. https://doi.org/10.1177/0003122413506440

17. Lambert, N.M., Stillman, T.F., Hicks, J.A., Kamble, S., Baumeister, R.F., Fincham, F.D. 2013. To belong is to matter: Sense of belonging enhances meaning in life. Personality and Social Psychology Bulletin, Vol. 39(11), pp. 1418-1427. https://doi.org/10.1177/0146167213499186

18. Lin, N. 1999. Building a network theory of social capital. Connections, Vo. 22(1), pp. 28-51.

19. Lucas, M., Gunawardena, C., Moreira, A. 2014. Assessing social construction of knowledge online: A critique of the interaction analysis model. Computers in Human Behavior, Vol. 30, pp. 574-582. https://doi.org/10.1016/j.chb.2013.07.050

20. Portes, A. 1998. Social capital: Its origins and applications in modern sociology. Annual review of sociology, Vol. 24(1), pp. 1-24. https://doi.org/10.1146/annurev.soc.24.1.1

21. Seidman, G. 2013. Self-presentation and belonging on Facebook: How personality influences social media use and motivations. Personality and Individual Differences, Vol. 54(3), pp. 402-407. https://doi.org/10.1016/j.paid.2012.10.009

22. Wellman, B., Haase, A.Q., Witte, J., Hampton, K. 2001. Does the Internet increase, decrease, or supplement social capital? Social networks, participation, and community commitment. American behavioral scientist, Vol. 45(3), pp. 436-455. https://doi.org/10.1177/00027640121957286

23. Williams, D. 2006. On and off the'Net: Scales for social capital in an online era. Journal of Computer-Mediated Communication, Vol. 11(2), pp. 593-628. https://doi.org/10.1111/j.1083-6101.2006.00029.x 